\title{
Oea
}

JURNAL PENDIDIKAN GEOGRAFI

\section{PERBEDAAN MODEL PEMBELAJARAN INKUIRI TERBIMBING DENGAN MODEL PEMBELAJARAN INKUIRI BEBAS PADA ASPEK KOGNITIF PESERTA DIDIK (Penelitian Eksperimen Pada Materi Geografi di Kelas X SMAN 6 Cimahi)}

\author{
Oleh \\ Ani Nuraini \\ Guru Geografi SMAN 6 Cimahi
}

\begin{abstract}
ABSTRAK
Penelitian ini dilatarbelakangi oleh permasalahan dalam pembelajaran geografi yaitu rendahnya aspek kognitif peserta didik terhadap materi pembelajaran geografi dan penggunaan model pembelajaran yang tepat dan efektif. Penggunaan model pembelajaran inkuiri terbimbing dan inkuiri bebas mendorong peserta didik untuk melibatkan secara maksimal seluruh kemampuan untuk mencari dan menyelidiki suatu fenomena dengan sistematis, kritis, logis dan analitis, sehingga peserta didik dapat merumuskan dan menyimpulkan hasil pembelajarannya. Subyek penelitian adalah peserta didik kelas X SMAN 6 Cimahi yang berjumlah 104 orang. Teknik pengumpulan data dengan observasi dan teknik tes (pre tes dan post tes). Hasil analisis data menunjukkan: 1) Terdapat perbedaan yang signifikan model pembelajaran inkuiri terbimbing dengan model pembelajaran inkuiri bebas pada aspek kognitif peserta didik, dengan nilai sig.(p-value) $0,0332<0,05$. 2) Terdapat perbedaan yang signifikan model pembelajaran inkuiri terbimbing dengan model pembelajaran konvensional pada aspek kognitif peserta didik, dengan nilai sig. (p-value) $0,004<0,05$. 3) Tidak terdapat perbedaan yang signifikan model pembelajaran inkuiri bebas dengan model pembelajaran konvensional pada aspek kognitif peserta didik, dengan nilai sig. (p-value) 0,219>0,05.
\end{abstract}

Kata kunci: Inkuiri Terbimbing, Inkuiri Bebas, Aspek Kognitif

\section{PENDAHULUAN}

Pada dasarnya pendidikan adalah unsur terpenting di dalam diri sebuah negara. Karena dari pendidikanlah lahir para sumber daya manusia yang handal. Karena itu pendidikan di dalam suatu negara harus dikelola dengan baik, jika diabaikan maka sudah dapat dipastikan anak bangsa yang lahir sebagai penerus untuk membangun negara akan menjadi seorang yang tak berdaya tergerus oleh jaman dan akan berdampak pada kelangsungan hidup suatu negara.

Menurut Sumarmi (2012: 3) ada tiga faktor yang sangat berpengaruh terhadap keberhasilan pendidikan yaitu pertama perangkat keras (hardware), yang meliputi ruang 
belajar, peralatan praktik, laboratorium, dan perpustakaan, kedua perangkat lunak (software) yang meliputi kurikulum, program pembelajaran, manajemen sekolah, system pembelajaran, dan lain-lain, ketiga perangkat pikir (brainware) yaitu guru, kepala sekolah, anak didik, dan orang-orang yang terkait dalam proses tersebut. Berdasarkan penjelasan tersebut guru memiliki peran yang sangat penting, karena penggunaan hardware dan software secara efektif dan efisien sangat berkaitan dengan inovasi guru untuk mencapai pembelajaran.

Dalam proses pembelajaran, guru sebagai komponen paling penting yaitu sebagai pengelola, fasilitator, pembimbing, motivator dan asessmen (Sumarmi, 2012: 3-4). Berdasarkan komponen professional guru tersebut maka guru harus mampu menumbuhkan dan meningkatkan pemahaman materi pelajaran peserta didik yang bukan bersifat hafalan saja dan bukan sekedar menyampaikan materi saja. Proses pembelajaran yang demikian sebagian besar masih menjadikan anak tidak bisa, menjadi bisa dan kegiatan belajar tersebut masih berupa kegiatan menambah pengetahuan, kegiatan menghadiri, mendengar dan mencatat penjelasan guru, serta menjawab secara tertulis soal-soal yang diberikan saat berlangsungnya ujian. Pembelajaran seperti itu masih mengimplementasikan pada tataran proses menyampaikan, memberikan, mentransfer ilmu pengetahuan dari guru kepada peserta didik. Dalam tataran ini peserta didik yang sedang belajar bersifat pasif, menerima apa saja yang diberikan guru, tanpa diberikan kesempatan untuk membangun sendiri pengetahuan yang dibutuhkan dan diminatinya.

Sumarmi (2012: 4-5) mengemukakan permasalahan dalam pembelajaran geografi di sekolah, adalah rendahnya pemahaman peserta didik terhadap materi ajar geografi, yaitu: 1). Banyak peserta didik mampu menghafal dengan baik terhadap konsep-konsep Geografi, baik konsep konkret maupun konsep abstrak yang diterimanya, tetapi pada kenyataanya mereka tidak memahami maknanya. 2). Sebagian besar peserta didik tidak mampu menghubungkan antara apa yang mereka pelajari di sekolah dengan bagaimana pengetahuan tersebut akan dipergunakan atau dimanfaatkan di masyarakat. Berdasarkan pernyataan Sumarmi tersebut, permasalahan pembelajaran geografi di sekolah yaitu pemahaman peserta didik terhadap makna dari konsep geografi setelah peserta didik mempelajari konsep-konsep materi pelajaran geografi sehingga hanya bentuk hafalan saja yang muncul pada kemampuan peserta didik dan kemampuan peserta didik belum dapat menghubungkan materi pelajaran geografi dengan pemanfaatan pengetahuan yang peserta didik dapatkan dalam kehidupan lingkungan masyarakat. Maka diperlukan suatu usaha berupa proses pembelajaran geografi yang lebih baik, sehingga permasalahan tersebut dapat ditanggulangi. 
Berdasarkan pengalaman penulis mengajar di SMAN 6 Cimahi, yaitu masih banyaknya peserta didik yang belum mampu mencapai kompetensi dasar pada suatu konsep materi pelajaran Geografi dalam proses pembelajaran. Pengalaman dalam proses pembelajaran Geografi di SMAN 6 Cimahi pada kelas X, tidak tercapainya hasil belajar yang maksimal diantaranya paradigma lama yang masih dipakai dalam pembelajaran Geografi di SMAN 6 Cimahi pada kels $\mathrm{X}$, dimana guru memberikan pengetahuan kepada peserta didik yang pasif. Guru mengajar dengan metode konvensional yaitu metode ceramah dan mengharapkan peserta didik duduk, diam, dengar, catat dan hafal (3DCH) Sehingga Kegiatan Belajar Mengajar (KBM) menjadi monoton dan kurang menarik perhatian peserta didik. Kondisi seperti itu dapat menimbulkan permasalahan yaitu tidak tercapainya tujuan pembelajaran Geografi dan kurangnya kemampuan peserta didik dalam memahami mata pelajaran Geografi. Akibatnya hasil belajar yang dicapai peserta didik tidak seperti yang diharapkan.

Penelitian ini bertujuan untuk mengukur kemampuan aspek kognitif peserta didik terhadap materi geografi fisik dengan menggunakan model pembelajaran inkuiri terbimbing (Guided Inquiry). model pembelajaran inkuiri tidak terbimbing (Free Inquiry) dan dengan menggunakan model pembelajaran konvensional.

Penelitian ini diharapkan dapat bermanfaat untuk peserta didik, agar lebih aktif dalam belajar geografi dan meningkatkan aspek kognitif serta peserta didik mendapatkan pengalaman belajar yang baru dan menyenangkan. Untuk guru dapat menerapkan model pembelajaran yang tepat dalam upaya menumbuhkan pemahaman dan meningkatkan aspek kognitif peserta didik dalam kegiatan pembelajaran geografi dan untuk sekolah, agar dapat meningkatkan kemampuan para guru dalam mengembangkan model-model pembelajaran yang tepat dalam kegiatan pembelajaran.

\section{KAJIAN PUSTAKA}

\section{a. Model Pembelajaran}

Model pembelajaran menurut Depdiknas (2009: 4) adalah bentuk pembelajaran yang menggambarkan kegiatan dari awal sampai akhir yang disajikan secara khas oleh guru. Selanjutnya di jelaskan pula bahwa dalam model pembelajaran terdapat strategi pencapaian kompetensi peserta didik dengan pendekatan, metode dan teknik pembelajaran tertentu.

Pemilihan model pembelajaran untuk diterapkan guru di dalam kelas mempertimbangkan beberapa hal, yaitu tujuan pembelajaran, sifat materi pelajaran, ketersediaan fasilitas, kondisi peserta didik dan alokasi waktu yang tersedia. Sehingga 
diharapkan dengan menggunakan model pembelajaran yang tepat dan sesuai beberapa pertimbangan tersebut, keseluruhan proses kegiatan belajar mengajar menjadi lebih baik dan medapat mencapai tujuan yang diharapkan dalam dunia pendidikan.

Menurut Joyce, Weil, dkk (2009: 30) menjelaskan bahwa model pembelajaran merupakan gambaran suatu lingkungan pembelajaran, yang juga meliputi prilaku kita sebagai guru dan memiliki banyak kegunaan yang menjangkau segala bidang pendidikan, mulai dari materi perancanaan dan kurikulum hingga materi perancangan instruksional. Joyce, Weil, dkk (2009: 31) mengelompokkan model pengajaran menjadi empat kelompok, yaitu: 1) Kelompok Model Pengajaran Memproses Informasi (The Information-Processing Family). 2) Kelompok Model Pengajaran Sosial (The Social Family). 3) Kelompok Model Pengajaran Personal (The Personal Family), dan 3) Kelompok Model Pengajaran Sistem Prilaku (The Behavioral System Family). Model pembelajaran dalam rumpun pengolahan informasi berdasarkan prinsipprinsip pengolahan informasi, yaitu pada bagaimana manusia menangani rangsangan dari lingkungan, mengorganisasi data, mengenali masalah dan mencoba solusinya. Model pembelajaran memproses informasi berhubungan dengan kemampuan peserta didik untuk memecahkan masalah, sehingga termasuk dalam kelompok model pembelajaran inkuiri. Model pembelajaran mengolah informasi, diantaranya adalah model pembelajaran inkuiri, yaitu model pembelajaran yang menngedepankan fakta berdasarkan teori. Pada model pembelajaran pelatihan inkuiri ini, peserta didik dihadapkan pada suatu masalah, merumuskan jawaban sementara atau hipotesis, merancang cara pembuktian dan menyimpulkan hasil.

\section{a. Model Pembelajaran Inkuiri}

Definisi menurut CEIRP (Cornell Environmental Inquiry Research Partnership) inkuiri merupakan proses dimana peserta didik mengajukan pertanyaan ilmiah dan bekerja untuk menjawab pertanyaan itu dengan sistematik (Avery, 1., et. al. 2003:3). Pengertian ini senada dengan pengertian inkuiri dari NSES (the National Science Education Standards) bahwa inkuiri adalah serangkaian aktivitas yang membangun pengetahuan peserta didik dan memahami ide-ide ilmiah sebaik memahami bagaimana para ilmuwan mempelajari gejalagejala alam (Avery, 1., et. al: 2003:3).

Adapun pendekatan inkuiri yang dapat diaplikasikan pada pembelajaran terdiri atas beberapa tipe. Carin (1980: 105) memaparkan bahwa terdapat dua tipe inkuiri yaitu (1) free inquiry atau inkuiri bebas dan (2) Guided inquiry atau inkuiri terbimbing. Pada tipe inkuiri bebas, peserta didik akan mengidentifkasi atau mengorganisasi sendiri masalah yang akan mereka kaji. Sedangkan pada tipe inkuiri terbimbing, guru menjadi fasilitator, nara sumber dan 
pembimbing (guide) selama proses pembelajaran berlangsung, dalam hal ini guru memberi arahan tentang bagaimana prosedur yang harus dilakukan dari awal hingga akhir kegiatan.

Model pembelajaran inkuiri banyak di pengaruhi oleh aliran belajar kognitif. Hal ini seperti yang dijelaskan oleh Sanjaya (2006: 195) bahwa model pembelajaran inkuiri, pada hakikatnya adalah proses mental dan proses berpikir dengan memanfaatkan segala potensi yang dimiliki setiap individu secara optimal. Teori lainnya yang mendasari model pembelajaran inkuiri adalah teori konstruktivistik yang dikembangkan oleh Piaget dalam Sanjaya (2006: 196) yaitu pengetahuan itu akan bermakna manakala dicari dan ditemukan sendiri oleh peserta didik.

Menurut Kuhlthau dalam Sumarmi (2012: 17) Inkuiri adalah pendekatan pembelajaran di mana peserta didik menemukan, menggunakan variasi sumber informasi dan ide untuk lebih memahami, suatu permasalahan, topik, atau isu. Hal ini tidak hanya sekedar menjawab pertanyaan tetapi juga melalui investigasi, eksplorasi, mencari, bertanya, meneliti dan mempelajari. Inkuiri tidak berdiri sendiri tetapi menyatu dengan interest, tantangan bagi murid untuk menghubungkan kurikulum dengan dunia nyata.

Ciri utama dalam pembelajaran inkuiri, peserta didik diharapkan dapat mengembangkan keterampilan berpikir kritis. Sanjaya (2006:196-197) menjelaskan ciri utama dari pembelajaran inkuiri yaitu menekankan pada aktivitas peserta didik secara maksimal untuk mencari dan menemukan dan peserta didik sebagai subjek belajar, seluruh aktivitas yang dilakukan pserta didik diarahkan untuk mencari dan menemukan jawaban sendiri dari sesuatu yang dipertanyakan, sehingga diharapkan dapat menumbuhkan sikap percaya diri dan mengembangkan kemampuan berpikir secara sistematis, logis dan kritis.

5 Langkah-langkah pembelajaran inkuiri meliputi proses inkuiri yang dilakukan melalui beberapa tahapan. Menurut Sanjaya (2006: 202-205) terdiri dari 5 tahapan ditambah 1 tahapan diawal pembelajaran,: 1) Orientasi, guru mengkondisikan agar peserta didik siap melaksanakan proses pembelajaran 2) Merumuskan masalah, membawa peserta didik pada suatu persoalan yang mengandung teka-teki. Persoalan yang disajikan adalah persoalan yang menantang siswa untuk berpikir memecahkan teka-teki tersebut. 3) Merumuskan hipotesis, memberikan jawaban sementara dari suatu permasalahan yang sedang dikaji. 4) Mengumpulkan data, aktivitas menjaring informasi yang dibutuhkan untuk menguji hipotesis yang diajukan. 5)Menguji hipotesis, adalah proses menentukan jawaban yang dianggap diterima sesuai dengan data atau informasi yang diperoleh berdasarkan pengumpulan data.6) Merumuskan kesimpulan, adalah proses mendeskripsikan temuan yang diperoleh berdasarkan hasil pengujian hipotesis. 


\section{b. Aspek Kognitif dalam Pembelajaran}

Menurut Piaget (dalam Dahar, 2011:131) menyebutkan bahwa kognitif adalah bagaimana anak beradaptasi dan menginterpretasikan objek dan kejadian-kejadian di sekitarnya. Piaget memandang bahwa anak memainkan peran aktif di dalam menyusun pengetahuannya mengenai realitas, anak tidak pasif menerima informasi. Selanjutnya walaupun proses berpikir dan konsepsi anak mengenai realitas telah dimodifikasi oleh pengalamannya dengan dunia sekitar dia, namun anak juga aktif menginterpretasikan informasi yang ia peroleh dari pengalaman, serta dalam mengadaptasikannya pada pengetahuan dan konsepsi.

Teori-teori kognitif didasarkan pada asumsi bahwa kemampuan kognitif merupakan sesuatu yang fundamental dan yang membimbing tingkah laku anak. Dengan kemampuan kognitif ini maka anak dipandang sebagai individu yang secara aktif membangun sendiri pengetahuan mereka tentang dunia. Perkembangan kognitif merupakan salah satu perkembangan manusia yang berkaitan dengan pengetahuan, yakni semua proses psikologis yang berkaitan dengan bagaimana individu mempelajari dan memikirkan lingkungannya.

Perumusan aspek-aspek kemampuan yang menggambarkan output peserta didik yang dihasilkan dari proses pembelajaran dapat digolongkan kedalam tiga klasifikasi berdasarkan taksonomi Bloom. Bloom menamakan cara mengklasifikasi itu dengan nama "The Taxonomy of Education Objektives". Menurut Bloom (Sukmadinata, 2009: 180) tujuan itu dikelompokkan dalam tiga ranah, yaitu: 1) Ranah kognitif (cognitive domain), berkenaan dengan kemampuan dan kecakapan-kecakapan berfikir. 2) Ranah afektif (afektive domain), berkenaan dengan kemampuan dan kecakapan yang berkaitan dengan emosional atau perasaan. 3) Ranah psikomotor (psychomotor domain), berkenaan dengan kemampuan dan kecakapan keterampilan.

Bloom menguraikan ketiga ranah menjadi beberapa aspek yang menjadi indikator dari ketiga ranah tersebut (Gulo, 2005: 51), yaitu: (1) kawasan kognitif yaitu kawasan yang berkaitan aspek-aspek intelektual atau berfikir/nalar, di dakamnya mencakup: pengetahuan (knowledge), pemahaman (comprehension), penerapan (application), penguraian (analysis), memadukan (synthesis), dan penilaian (evaluation); (2) kawasan afektif yaitu kawasan yang berkaitan aspek-aspek emosional, seperti perasaan, minat, sikap, kepatuhan terhadap moral dan sebagainya, di dalamnya mencakup: penerimaan (receiving/attending), sambutan (responding), penilaian (valuing), pengorganisasian (organization), dan karakterisasi (characterization); dan (3) kawasan psikomotor yaitu kawasan yang berkaitan dengan aspekaspek keterampilan yang melibatkan fungsi sistem syaraf dan otot (neuronmuscular system) 
dan fungsi psikis. Kawasan ini terdiri dari: kesiapan (set), peniruan (imitation, membiasakan (habitual), menyesuaikan (adaptation) dan menciptakan (origination). Taksonomi ini merupakan kriteria yang dapat digunakan oleh guru untuk mengevaluasi mutu dan efektivitas pembelajarannya.

Menurut Bloom (Sukmadinata, 2009: 181) dijelaskan bahwa ranah kognitif menggolongkan dan mengurutkan keahlian berpikir yang menggambarkan tujuan yang diharapkan. Proses berfikir mengekspresikan tahap-tahap kemampuan yang harus dikuasai peserta didik sehingga menunjukkan kemampuan mengolah pikirannya agar mampu mengaplikasikan teori kedalam perbuatan.

Dalam struktur taksonomi pendidikan yang dikembangkan oleh Benjamin Bloom kemudian di revisi oleh Anderson dan Krathwohl (2010: 43) terdapat 6 kategori pada dimensi proses kognitif. berikut tabel 1. yang mendeskripsikan dari dimensi proses kognitif tersebut:

Tabel 1. Deskripsi Enam Kategori pada Dimensi Proses Kognitif dan Kata Kunci

\begin{tabular}{|c|c|}
\hline Kategori Proses & Proses Kognitif dan Kata Kunci \\
\hline 1. MENGINGAT & Mengambil pengetahuan dari memori jangka panjang \\
\hline $\begin{array}{ll}\text { 1.1. } & \text { Mengenali } \\
\text { 1.2. } & \text { Mengingat Kembali }\end{array}$ & $\begin{array}{l}\text { Menyebutkan definisi, menirukan ucapan } \\
\text { Menyatakan susunan, mengucapkan, mengulang, } \\
\text { menyatakan }\end{array}$ \\
\hline 2. MEMAHAMI & $\begin{array}{l}\text { Mengkonstruk makna dari materi pembelajaran, termasuk } \\
\text { apa yang diucapkan, ditulis, dan digambar oleh guru }\end{array}$ \\
\hline 2.1.Menafsirkan & Memfrasekan ucapan dan teori \\
\hline 2.2.Mencontohkan & Memberi contoh \\
\hline 2.3.Mengklasifikasikan & Mengklasifikasikan, mengelompokkan \\
\hline 2.4.Merangkum & Menuliskan ringkasan \\
\hline 2.5.Menyimpulkan & Menyimpulkan, menterjemahkan \\
\hline 2.6.Membandingkan & Membandingkan \\
\hline 2.7.Menjelaskan & Menjelaskan sebab terjadinya \\
\hline 3. MENGAPLIKASIKAN & $\begin{array}{l}\text { Menerapkan atau menggunakan suatu prosedur dalam } \\
\text { keadaan tertentu }\end{array}$ \\
\hline $\begin{array}{l}\text { 3.1.Mengeksekusi } \\
\text { 3.2.Mengimplementasikan }\end{array}$ & $\begin{array}{l}\text { Memilih, menggunakan, memecahkan masalah } \\
\text { Mendemontrasikan, memerankan, mengilustrasikan }\end{array}$ \\
\hline 4. MENGANALISIS & $\begin{array}{l}\text { Memecah-mecah materi jadi bagian-bagian penyusunnya } \\
\text { dan menentukan hubungan-hubungan antar bagian itu dan } \\
\text { hubungan antara bagian-bagian tersebut dan keseluruhan } \\
\text { struktur atau tujuan. }\end{array}$ \\
\hline $\begin{array}{l}\text { 4.1.Membedakan } \\
\text { 4.2.Mengorganisasi } \\
\text { 4.3.Mengatribusikan } \\
\end{array}$ & $\begin{array}{l}\text { Mengkaji, membandingkan, mengkontraskan, } \\
\text { membedakan, melakukan diskriminasi, memisahkan, } \\
\text { menguji, melakukan eksperimen, mempertanyakan }\end{array}$ \\
\hline 5. MENGEVALUASI & $\begin{array}{l}\text { Mengambil keputusan berdasarkan kriteria dan atau } \\
\text { standar }\end{array}$ \\
\hline $\begin{array}{l}\text { 5.1.Memeriksa } \\
\text { 5.2.Mengkritik }\end{array}$ & $\begin{array}{l}\text { Memberikan argumentasi, mempertahankan, menyatakan, } \\
\text { memilih, member dukungan, memberi penilaian, } \\
\text { melakukan evaluasi }\end{array}$ \\
\hline
\end{tabular}




\begin{tabular}{|ll|}
\hline 6. MENCIPTA & $\begin{array}{l}\text { Memadukan bagian-bagian untuk membentuk sesuatu } \\
\text { yang baru dan koheren atau untuk membuat suatu produk } \\
\\
\text { yang orisinal. }\end{array}$ \\
\hline 6.1.Merumuskan & Merumuskan hipotesis, mencipta \\
6.2.Merencanakan & Merencanakan, merancang \\
6.3.Memproduksi & Membuat, membangun, mendirikan, mengubah, menulis \\
\hline
\end{tabular}

Sumber: Anderson dan Krathwohl (2010: 44-45)

\section{c. Materi Pembelajaran Geografi Fisik}

Strahler (1960: 1) menjelaskan pengertian geografi fisik (physical geography) sebagai penyatuan studi dari sejumlah ilmu bumi yang akan memberikan kita wawasan secara umum, serta menjadikan bagian dari lingkungan manusia. Strahler juga menjelaskan bahwa geografi fisik tidak berdiri sendiri tetapi terdiri dari beberapa cabang keimuan. Geografi fisik adalah tubuh prinsip dari dasar ilmu bumi yang paling berperan dalam mempelajari pengaruh lingkungan terhadap kehidupan di bumi terutama pengaruh lingkungan yang mengakibatkan terjadinya variasi dan penyebarannya dari satu tempat ke tempat lainnya di permukaan bumi.

Menurut Strahler dan Strahler (dalam Purnomo,2012: 12) geografi secara sistematis dibagi dalam dua kelompok besar yaitu geografi fisik dan geografi manusia. Geografi fisik didefinisikan sebagai studi distribusi dan saling hubungan fenomena-fenomena alami dari litosfer, atmosfer, hidrosfer, dan biosfer. Menurut Strahler (1960: 2) geografi fisik mencakup bumi, elemen cuaca, iklim dan tanah serta lahan. Penjelasan lebih lanjut dikemukakan kembali oleh Strahler dan Strahler (dalam Purnomo, 2012: 12) bahwa geografi fisik tidak hanya sekedar mempelajari kondisi fisik permukaan bumi, akan tetapi mencakup studi tentang tanah, lautan, atmosfer, batuan, air, vegetasi, dan binatang. Lima bidang besar geografi fisik meliputi klimatologi, geomorfologi, geografi pesisir dan kelautan, geografi tanah, dan biogeografi, sementara itu sumberdaya air dan penilaian bencana merupakan bidang terapan yang penting bagi geografi fisik.

Pada latar belakang mata pelajaran Geografi untuk SMA (Kurikulum KTSP, 2009: 303) dijelaskan bidang kajian geografi meliputi bumi, aspek dan proses yang membentuknya, hubungan kausal dan spasial manusia dengan lingkungan, serta interaksi manusia dengan tempat. Sebagai suatu disiplin integratif, geografi memadukan dimensi alam fisik dengan dimensi manusia dalam menelaah keberadaan dan kehidupan manusia di tempat dan lingkungannya.

Pada Kurikulum KTSP (2009: 305) Standar kompetensi dan kompetensi dasar mata pelajaran geografi, yang berkaitan dengan geografi fisik terdapat pada kelas X semester 2,. 
Berikut pemaparan SK dan KD yang berkaitan dengan materi pembelajaran geografi fisik pada tabel 2 berikut ini:

Tabel 2. Standar Kompetensi dan Kompetensi Dasar Mata Pelajaran Geografi Kelas X Semester 2

\begin{tabular}{|c|c|}
\hline Standar Kompetensi & Kompetensi Dasar \\
\hline $\begin{array}{l}\text { 3. Menganalisis unsur-unsur } \\
\text { geosfer }\end{array}$ & $\begin{array}{l}\text { 3.1. Menganalisis dinamika dan kecenderungan perubahan } \\
\text { litosfer dan pedosfer serta dampaknya terhadap } \\
\text { kehidupan di muka bumi } \\
\text { 3.2 } \begin{array}{l}\text { Menganalisis atmosfer dan dampaknya terhadap } \\
\text { kehidupan di muka bumi }\end{array} \\
\text { 3.3 Menganalisis hidrosfer dan dampaknya terhadap } \\
\text { kehidupan di muka bumi }\end{array}$ \\
\hline
\end{tabular}

Berdasarkan tabel 2. standar kompetensi dan kompetensi dasar tersebut, maka pembelajaran geografi tidak hanya mempelajari deskripsi tentang bumi atau permukaan bumi, melainkan meliputi juga analisis hubungan antara aspek fisik dengan aspek manusia.

\section{d. Hipotesis Penelitian}

Hipotesis yang diajukan dalam penelitian ini, adalah sebagai berikut: 1) $\mathrm{H}_{1}$ : Terdapat perbedaan model pembelajaran inkuiri terbimbing dengan model pembelajaran inkuiri bebas pada aspek kognitif peserta didik . 2) $\mathrm{H}_{2}$ : Terdapat perbedaaan model pembelajaran inkuiri terbimbing dengan model pembelajaran konvensional pada aspek kognitif peserta didik . 3) $\mathrm{H}_{3}$ : Terdapat perbedaaan antara model pembelajaran inkuiri bebas dengan model pembelajaran konvensional pada aspek kognitif peserta didik.

\section{METODE PENELITIAN}

Penelitian kuasi eksperimen ini di laksanakan pada tanggal 27 Maret 2013 sampai dengan tanggal 24 April 2013. Menggunakan 2 kelas eksperimen dan 1 kleas kontrol, yaitu di kelas X-9 sebagai kelas eksperimen 1, kelas X-8 sebagai kelas eksperimen 2 dan kelas X-10 sebagai kelas kontrol. Dengan Kompetensi dasar menganalisis unsur-unsur atmosfer dan dampaknya terhadap kehidupan dibumi. Terdiri dari tiga pokok bahasan, yaitu atmosfer, unsurunsur cuaca dan iklim, dan klasifikasi tipe iklim. Teknik pengumpulan data menggunakan observasi keterlaksanaan model pembelajaran yang dilakukan oleh guru dan teknik tes, untuk mengukur aspek kognitif peserta didik. Observasi dilakukan dengan lembar observasi yang dilakukan oleh observer selama tiga kali pertemuan kegiatan pembelajaran di kelas penelitian dan teknik tes dengan melakukan pre tes sebelum kegiatan pembelajaran di lakukan dan post 
tes setelah perlakuan terhadap kelas penelitian, sehingga dapat dilihat hasil pengukuran aspek kognitif peserta didik sebelum dan sesudah perlakuan.

\section{HASIL ANALISIS DATA DAN PEMBAHASAN}

\section{a. Data Hasil Pengukuran Aspek Kognitif Peserta Didik}

Hasil pengukuran data aspek kognitif peserta didik didapatkan melalui pre tes dan post tes. Dari skor pre tes dan post tes selanjutnya dihitung nilai rata-rata skor tes dan menghitung nilai gain ternormalisasi ( $\mathrm{N}$-gain) aspek kognitif peserta didik kelas eksperimen 1, kelas eksperimen 2 dan kelas kontrol. Rata-rata N-gain diperoleh sebagai gambaran peningkatan aspek kognitif peserta didik yang mendapatkan model pembelajaran inkuiri terbimbing (Guided Inquiry), model pembelajaran inkuiri bebas (Free inquiry) dan dengan model pembelajaran konvensional. Rangkuman rata-rata skor pre tes, post tes, dan $\mathrm{N}$-gain aspek kognitif pada kelas eksperimen 1, eksperimen 2 dan kelas kontrol dapat dilihat pada tabel 3 berikut ini:

Tabel 3. Rata-rata Skor Pre tes, Post tes dan N-gain Aspek Kognitif

\begin{tabular}{|c|c|c|c|}
\hline Hasil & $\begin{array}{c}\text { Kelas Eksperimen 1 } \\
\text { Inkuiri Terbimbing }\end{array}$ & $\begin{array}{c}\text { Kelas Eksperimen 2 } \\
\text { Inkuiri Bebas }\end{array}$ & $\begin{array}{c}\text { Kelas Kontrol } \\
\text { Konvensional }\end{array}$ \\
\hline Pre tes & 15,69 & 15,31 & 15,35 \\
\hline Post tes & 20,26 & 18,63 & 17,85 \\
\hline N- gain & 0,32 & 0,24 & 0,17 \\
\hline \multicolumn{2}{|r}{} & Sumber: Hasil Penelitian, 2013
\end{tabular}

Berdasarkan tabel 3. menggambarkan rata-rata skor pre tes peserta didik kelas eksperimen 1 sebesar 15,69; kelas eksperimen 2 sebesar 15,31; dan kelas kontrol sebesar 15,35. Rata-rata skor pos tes kelas eksperimen 1 sebesar 20,26; kelas eksperimen 2 sebesar 18,63 dan kelas kontrol sebesar 17,85. Berdasarkan paparan data pre tes dan post tes tersebut menggambarkan terjadinya peningkatan skor post tes pada kelas eksperimen 1, kelas eksperimen 2 dan kelas kontrol. Kemudian rata-rata N-gain aspek kognitif kelas eksperimen 1 sebesar 0.32 ; kelas eksperimen 2 sebesar 0,24; dan kelas kontrol sebesar 0,17. Rata-rata Ngain kelas eksperimen 1 termasuk kategori sedang, sedangkan rata-rata $\mathrm{N}$-gain kelas eksperimen 2 dan kelas kontrol termasuk rendah. Kuantitas N-gain dari ketiga kelas menunjukkan perbedaan peningkatan.

\section{b. Uji Statistik}




\section{1) Uji Normalitas}

Uji normalitas dilakukan terhadap hasil pre tes dan post tes untuk menentukan data tersebut terdistribusi secara normal atau tidak. Uji normalitas menggunakan KolmogorovSmirnov (normality test) terhadap skor pre tes dan post tes kelas eksperimen 1, kelas eksperimen 2, dan kelompok Kontrol. Uji normalitas Kolmogorov-Smirnov dengan bantuan program Minitab V.16. Jika hasil uji Kolmogorov-Smirnov nilai signifikan (P - Value) $\geq \alpha(\alpha$ $=0,05)$, maka data tersebut terdistribusi normal. Rangkuman hasil uji normalitas terdapat tabel 4. Berikut ini:

Tabel 4. Uji Normalitas

\begin{tabular}{|c|l|c|c|c|c|}
\hline \multirow{2}{*}{ Hasil } & \multirow{2}{*}{ Kelas } & \multicolumn{2}{|c|}{ Kolmogorov - Smirnov } & \multirow{2}{*}{ Keterangan } \\
\cline { 3 - 6 } & & Statistik & $\mathbf{N}$ & P -value & \\
\hline \multirow{4}{*}{ Pre tes } & Inkuiri Terbimbing & 0,131 & 35 & 0,129 & Data Beridistribusi Normal \\
\cline { 2 - 6 } & Inkuiri Bebas & 0,132 & 35 & 0,122 & Data Beridistribusi Normal \\
\cline { 2 - 6 } & Konvensional & 0,119 & 34 & $>0,150$ & Data Beridistribusi Normal \\
\hline \multirow{4}{*}{ Post tes } & Inkuiri Terbimbing & 0,121 & 35 & $>0,150$ & Data Beridistribusi Normal \\
\cline { 2 - 6 } & Inkuiri Bebas & 0,140 & 35 & 0,082 & Data Beridistribusi Normal \\
\cline { 2 - 6 } & Konvensional & 0,075 & 34 & $>0,150$ & Data Beridistribusi Normal \\
\hline \multirow{3}{*}{ Gain } & Inkuiri Terbimbing & 0,323 & 35 & $>0,150$ & Data Beridistribusi Normal \\
\cline { 2 - 6 } & Inkuiri Bebas & 0,241 & 35 & 0,114 & Data Beridistribusi Normal \\
\cline { 2 - 6 } & Konvensional & 0,170 & 34 & $>0,150$ & Data Beridistribusi Normal \\
\hline
\end{tabular}

Berdasarkan tabel 4. skor pre tes, post tes aspek kognitif peserta didik kelas eksperimen 1, kelas eksperimen 2 dan kelas kontrol memiliki nilai $p$-value $\geq \alpha(\alpha=0,05)$, sehingga dari perhitungan uji normalitas tersebut menunjukkan bahwa data pre tes dan post tes aspek kognitif peserta didik kelas eksperimen 1, kelas eksperimen 2, dan kelas kontrol berdistribusi normal.

\section{2) Uji Homogenitas}

Uji homogenitas varians skor pre tes dan post tes menggunakan uji Levene dengan bantuan program Minitab V.16, pada taraf signifikan $\alpha=0,05$. Jika uji Levene nilai signifikan (P-Value) $\geq 0,05$ maka data tersebut homogen. Rangkuman perhitungan uji homogenitas terdapat pada tabel 5 .

Tabel 5. Uji Homogenitas

\begin{tabular}{|c|c|c|c|c|c|}
\hline Kelas & Levene Statistic & DF1 & DF2 & P-Value & Kesimpulan \\
\hline Eksperimen 1 & 0,03 & 1 & 68 & 0,569 & Variansi Homogen \\
\hline Eksperimen 2 & 0,29 & 1 & 68 & 0,295 & Variansi Homogen \\
\hline Kelas Kontrol & 0,29 & 1 & 66 & 0,702 & Variansi Homogen \\
\hline
\end{tabular}


Pada tabel 5. hasil uji homogenitas dengan uji Levene pada eksperimen 1 dengan mengukur hasil skor pre tes dan post tes data berdistribusi normal dan homogen, pada eksperimen 2 mengukur hasil pre tes dan post tes data berdistribusi normal dan homogen, serta pada kelas kontrol mengukur hasil pre tes dan post tes data berdistribusi normal dan homogen.

\section{3) Uji Hipotesis}

Untuk menguji hipotesis dilakukan dengan uji t menggunakan program Minitab V.16. Pengukuran dilakukan dengan mengukur post tes kelas eksperimen 1 dengan post tes eksperimen 2, post tes eksperimen 1 dengan post tes kelas kontrol dan post tes kelas eksperimen 2 dengan post tes kelas kontrol.

\section{Pengujian Hipotesis 1}

Terdapat perbedaan antara model pembelajaran inkuiri terbimbing dengan model pembelajaran inkuiri bebas pada aspek kognitif peserta didik.

Hipotesis yang diajukan yakni:

$\mathrm{H}_{0}$ : Tidak terdapat perbedaan antara model pembelajaran inkuiri terbimbing dengan model pembelajaran inkuiri bebas pada aspek kognitif peserta didik.

Ha: Terdapat perbedaan antara model pembelajaran inkuiri terbimbing dengan model pembelajaran inkuiri bebas pada aspek kognitif peserta didik.

Berikut tabel 6 yang menggambarkan hasil pengukuran post tes kelas inkuiri terbimbing dengan inkuiri bebas, pada taraf signifikan $\alpha=0,05$.

Tabel 6. Uji Perbedaan Post Tes Kelas Inkuiri Terbimbing dengan Kelas Inkuiri Bebas

\begin{tabular}{|c|c|c|c|c|}
\hline \multicolumn{2}{|c|}{ Kolmogorov-Smirnov's Test } & \multirow{2}{*}{ Keterangan } & \multirow{2}{*}{ Kesimpulan } \\
\hline T & DF & P-Value & & \\
\hline 1,87 & 68 & 0,033 & $\mathrm{H}_{0}$ ditolak, Ha diterima & Terdapat Pengaruh \\
\hline
\end{tabular}

Berdasarkan tabel 6 terdapat nilai signifikansi (P-Value) dibawah 0,05 yaitu 0,033< 0,05. Maka $\mathrm{H}_{0}$ ditolak dan $\mathrm{H}_{\mathrm{a}}$ diterima, artinya terdapat perbedaan yang signifikan antara model pembelajaran inkuiri terbimbing dengan model pembelajaran inkuiri bebas pada aspek kognitif peserta didik. Hal ini di karenakan peserta didik di kelas inkuiri terbimbing lebih terarah menjalankan langkah-langkah pembelajaran inkuiri melalui arahan dan bimbingan guru sedangkan pada kelas inkuiri bebas peserta didik menjalankan langkah-langkah pembelajaran inkuiri melalui arahan guru tetapi mereka berusaha mencapai setiap langkah pembelajaran inkuiri secara mandiri

\section{a) Pengujian Hipotesis 2}


Terdapat perbedaan antara model pembelajaran inkuiri terbimbing dengan model konvensional pada aspek kognitif peserta didik.

Hipotesis yang diajukan yakni:

$\mathrm{H}_{0}$ : Tidak terdapat perbedaan antara model pembelajaran inkuiri terbimbing dengan model pembelajaran konvensional pada aspek kognitif peserta didik.

Ha: Terdapat perbedaan antara model pembelajaran inkuiri terbimbing dengan model pembelajaran konvensional pada aspek kognitif peserta didik. Berikut tabel 7 yang menggambarkan hasil perbedaan pengukuran post tes kelas inkuiri terbimbing dengan kelas inkuiri pada taraf signifikan $\alpha=0,05$.

Tabel 7. Uji Perbedaan Post Tes Kelas Inkuiri Terbimbing dengan Kelas Kontrol

\begin{tabular}{|c|c|c|c|c|}
\hline \multicolumn{2}{|c|}{ Kolmogorov-Smirnov's Test } & \multirow{2}{*}{ Keterangan } & \multirow{2}{*}{ Kesimpulan } \\
\hline T & DF & P-Value & & Terdapat Pengaruh \\
\hline 2,7 & 67 & 0,004 & $\mathrm{H}_{0}$ ditolak, Ha diterima & Sumber: Hasil Penelitian, 2013 \\
\hline
\end{tabular}

Berdasarkan tabel 7, terdapat nilai signifikansi (P-Value) dibawah 0,05 yaitu 0,004< 0,05. Maka $\mathrm{H}_{0}$ ditolak dan $\mathrm{H}_{\mathrm{a}}$ diterima, artinya terdapat perbedaan yang signifikan antara model pembelajaran inkuiri terbimbing dengan model pembelajaran konvensional padap aspek kognitif peserta didik.

\section{b) Pengujian Hipotesis 3}

Terdapat perbedaan antara model pembelajaran pembelajaran inkuiri bebas dengan model pembelajaran konvensional pada aspek kognitif peserta didik.

Hipotesis yang diajukan yakni:

$\mathrm{H}_{0}$ : Tidak terdapat perbedaan antara model pembelajaran inkuiri bebas dengan model pembelajaran konvensional pada aspek kognitif peserta didik.

Ha: Terdapat perbedaan antara model pembelajaran inkuiri bebas dengan model pembelajaran konvensional pada aspek kognitif peserta didik.

Berikut tabel 8 yang menggambarkan hasil perbedaan pengukuran post tes kelas inkuiri bebas dengan kelas konvensional, pada taraf signifikan $\alpha=0,05$.

Tabel 8. Uji Perbedaan Post Tes Kelas Inkuiri Terbimbing dengan Kelas Kontrol

\begin{tabular}{|c|c|c|c|c|}
\hline \multicolumn{2}{|c|}{ Kolmogorov-Smirnov's Test } & \multirow{2}{*}{ Keterangan } & \multirow{2}{*}{ Kesimpulan } \\
\hline T & DF & P-Value & & Tidak terdapat pengaruh \\
\hline 0,78 & 67 & 0,219 & Ho diterima & Sumber: Hasil Penelitian, 2013 \\
\hline
\end{tabular}


Berdasarkan tabel 4.6 terdapat nilai signifikansi (P-Value) diatas 0,05 yaitu 0,219>0,05. Maka $\mathrm{H}_{0}$ diterima dan $\mathrm{H}_{\mathrm{a}}$ ditolak, artinya tidak terdapat perbedaan antara model pembelajaran inkuiri bebas dengan konvensional terhadap aspek kognitif peserta didik pada materi geografi fisik. Berikut rangkuman hipotesis penelitian di deskripsikan pada tabel 9 berikut ini.

Tabel 9. Rangkuman Pengujian Hipotesis

\begin{tabular}{|l|l|c|}
\hline No & \multicolumn{1}{|c|}{ Hipotesis Penelitan } & Kesimpulan \\
\hline 1. & $\begin{array}{l}\text { Terdapat pengaruh model pembelajaran inkuiri terbimbing dengan } \\
\text { model pembelajaran inkuiri bebas terhadap aspek kognitif peserta } \\
\text { didik pada materi geografi fisik. } \\
\bullet \quad \text { Kelas Eksperimen 1 dengan Kelas Esperimen 2 }\end{array}$ & $\begin{array}{c}\text { Hipotesis } \\
\text { Diterima }\end{array}$ \\
\hline 2. & $\begin{array}{l}\text { Terdapat pengaruh model pembelajaran inkuiri terbimbing dengan } \\
\text { model pembelajaran konvensional terhadap aspek kognitif peserta } \\
\text { didik pada materi geografi fisik. } \\
\text { Kelas Eksperimen 1 dengan Kelas Kontrol }\end{array}$ & $\begin{array}{c}\text { Hipotesis } \\
\text { Diterima }\end{array}$ \\
\hline 3. & $\begin{array}{l}\text { Tidak terdapat pengaruh model pembelajaran inkuiri bebas dengan } \\
\text { model pembelajaran konvensional terhadap aspek kognitif peserta } \\
\text { didik pada materi geografi fisik. } \\
\text { Kelas Eksperimen 2 dengan Kelas Kontrol }\end{array}$ & Hipotesis \\
Ditolak
\end{tabular}

\section{c. Hasil Observasi}

Hasil observasi keterlaksanaan model pembelajaran inkuiri terbimbing dan inkuiri bebas pada kelas penelitian, berdasarkan hasil observer adalah sebagai berikut:

\section{1) Kelas Eksperimen 1}

Pertemuan pertama pada proses kegiatan belajar mengajar di kelas eksperimen 1, yaitu di kelas X.9. Guru memulai proses belajar saling mengucapkan salam dan berdo'a bersama. Guru memulai apersepsi dengan bertanya tentang pengertian atmosfer. Peserta didik dengan semangat mengemukakan pendapatnya secara bergantian. Kemudian guru menayangkan gambar/chart lapisan atmosfer dengan multimedia sebagai motivasi untuk peserta didik, berkaitan dengan materi atmosfer yang akan di pelajari.

Guru menjelaskan tujuan pembelajaran serta menjelaskan garis besar materi atmosfer. Peserta didik mengkaji kembali materi atmosfer melalui buku sumber dan tayangan multimedia. Pada konsep unsur-unsur yang terkandung di atmosfer dan fenomena yang akhir- 
akhir ini terjadi pada lapisan atmosfer, guru memberikan kesempatan peserta didik untuk mengemukakan pendapatnya dan peserta didik lainnya menanggapinya.

Pada konsep ciri-ciri lapisan atmosfer, guru menjelaskan model pembelajaran inkuiri terbimbing yang akan dipakai pada pembelajaran materi tersebut. Peserta didik memperhatikan langkah-langkah dalam model pembelajaran inkuiri terbimbing yang harus mereka tempuh.

Peserta didik dibagi menjadi 8 kelompok, tiap kelompok terdiri dari 4 atau 5 orang peserta didik. Tiap kelompok diberikan tugas materi ciri lapisan atmosfer yang berbeda-beda. Peserta didik di dalam kelompok mengerjakan lembar kerja siswa secara berkelompok dengan mengikuti arahan dan bimbingan guru di setiap langkah pembelajaran inkuiri terbimbing, yang terdiri dari 5 langkah yaitu merumuskan masalah, merumuskan hipotesis, mengumpulkan data, menguji hipotesis dan merumuskan kesimpulan. Berikut ini bentuk 5 langkah inkuiri terbimbing yang dilakukan peserta didik melalui bimbingan dan arahan guru terhadap peserta didik dalam kelompok.

1. Langkah merumuskan masalah, peserta didik dibimbing untuk merumuskan beberapa pertanyaan yang berkaitan dengan salah satu lapisan atmosfer,

2. Langkah merumuskan hipotesis, peserta didik dalam kelompok dibimbing guru untuk mengembangkan jawaban sementara dari pertanyaan yang mereka ajukan dalam rumusan masalah.

3. Langkah mengumpulkan data, peserta didik mengembangkan jawaban sementara yang mereka ajukan dengan mengumpulkan data melalui kajian berbagai sumber seperti buku paket dan teks lainnya.

4. Langkah menguji hipotesis dengan membuktikan hipotesis dengan contoh soal yang diberkaitan dengan ciri salah satu lapisan atmosfer.

5. Langkah merumuskan kesimpulan, dengan bimbingan dan arahan guru setiap kelompok membuat rumusan kesimpulan dari keseluruhan langkah pembelajaran inkuiri terbimbing dengan materi atmosfer.

Beberapa kelompok diberikan kesempatan untuk memaparkan hasil diskusi kelompok tentang konsep ciri-ciri lapisan atmosfer. Kelompok lain menanggapi hasil pemaparan kelompok lain.

Guru mengobservasi setiap langkah kegiatan model pembelajaran inkuiri terbimbing tiap kelompok dan memfasilitasi presentasi hasil diskusi kelompok. Peserta didik menyimpulkan hasil pembelajaran materi atmosfer dan guru mengumumkan penilaian hasil diskusi kelompok.

\section{2) Kelas Eksperimen 2}


Pembelajaran di kelas eksperimen 2 yaitu kelas X.8 dengan menggunakan model pembelajaran inkuiri bebas. Kegiatan belajar mengajar dimulai dengan saling mengucapkan salam dan berdo'a. Guru mengabsen peserta didik. Guru memulai dengan apersepsi yaitu dengan menanyakan tentang pengertian atmosfer, beberapa peserta didik menjawab dan menjelaskan sesuai dengan kemampuan dan pengetahuannya. Guru memotivasi peserta didik dengan menayangkan chart atau gambar lapisan atmosfer pada multimedia.

Guru menjelaskan tujuan pembelajaran dan materi yang akan di bahas secara garis besar dengan materi atmosfer, yaitu mengenai pengertian atmosfer, unsur-unsur yang terkandung di dalam atmosfer dan ciri-ciri tiap lapisan atmosfer serta peranan dan manfaat atmosfer.

Peserta didik mengkaji kembali konsep pengertian atmosfer dan unsure-unsur yang terkandung di dalam atmosfer kemudian mengemukakan kembali hasil kajiannya dengan tanya jawab antar peserta didik dan guru berperan sebagai fasilitator.

Pada konsep ciri-ciri lapisan atmosfer, guru menerangkan model pembelajaran yang akan di lakukan, yaitu inkuiri bebas. Peserta didik dibagi menjadi 8 kelompok, tiap kelompok terdiri dari 4 sampai 5 orang peserta didik. Tiap kelompok diberikan lembar kerja siswa untuk di kerjakan dengan menggunakan langkah-langkah inkuiri bebas. Guru memberikan arahan bagaimana langkah-langkah model pembelajaran inkuiri bebas yang harus peserta didik lakukan. Langkah pembelajaran inkuiri bebas terdiri dari 5 langkah yaitu merumuskan masalah, merumuskan hipotesis, mengumpulkan data, menguji hipotesis dan merumuskan kesimpulan. Dalam inkuiri bebas, peserta didik melakukan langkah-langkah pembelajaran dengan mandiri dengan menggunakan LKS sehingga diharapkan mereka tetap berada dalam koridor pembelajaran inkuiri. Berikut ini bentuk 5 langkah inkuiri bebas yang dilakukan peserta didik dalam kelompok:

1. Langkah merumuskan masalah, secara mandiri peserta didik merumuskan beberapa pertanyaan yang berkaitan dengan salah satu lapisan atmosfer,

2. Langkah merumuskan hipotesis, secara mandiri peserta didik dalam kelompok mengembangkan jawaban sementara dari pertanyaan yang mereka ajukan dalam rumusan masalah.

3. Langkah mengumpulkan data, dengan mandiri peserta didik mengembangkan jawaban sementara yang mereka ajukan dengan mengumpulkan data melalui kajian berbagai sumber seperti buku paket dan teks lainnya.

4. Langkah menguji hipotesis dengan membuktikan hipotesis dengan contoh soal yang diberkaitan dengan ciri salah satu lapisan atmosfer. 
5. Langkah merumuskan kesimpulan, dengan mandiri setiap kelompok membuat rumusan kesimpulan dari keseluruhan materi pembelajaran yang mereka pelajari bersama.

Beberapa kelompok diberikan kesempatan untuk memaparkan hasil diskusi kelompok tentang konsep ciri-ciri lapisan atmosfer. Kelompok lain menanggapi hasil pemaparan kelompok lain. Guru mengobservasi setiap langkah kegiatan model pembelajaran inkuiri bebas tiap kelompok dan memfasilitasi presentasi hasil diskusi kelompok. Peserta didik menyimpulkan hasil pembelajaran materi atmosfer dan guru mengumumkan penilaian hasil diskusi kelompok.

\section{KESIMPULAN DAN SARAN}

\section{a. Kesimpulan}

Berdasarkan hasil pemaparan rumusan masalah, data hasil penelitian dan pembahasan pada penelitian, penulis menarik kesimpulan hasil pengukuran setelah dilakukan eksperimen terhadap ketiga kelas penelitian yaitu kesimpulan pertama terdapat perbedaan pada aspek kognitif peserta didik antara kelas yang menggunakan model pembelajaran inkuiri terbimbing dengan kelas yang menggunakan model pembelajaran inkuiri bebas. Kesimpulan kedua yaitu terdapat perbedaan pada aspek kognitif peserta didik yang menggunakan model pembelajaran inkuiri terbimbing dengan kelas yang menggunakan model pembelajaran konvensional. Kesimpulan yang ketiga yaitu tidak terdapat perbedaan pada aspek kognitif peserta didik yang menggunakan model pembelajaran inkuiri bebas dengan model pembelajaran konvensional.

Penggunaan model pembelajaran inkuiri terbimbing terbukti memberikan pengaruh terhadap aspek kognitif peserta didik pada materi geografi fisik, karena model pembelajaran inkuiri terbimbing dapat memberikan motivasi bagi paserta didik untuk berpikir lebih tinggi dengan arahan dan bimbingan guru, sehingga tujuan pembelajaran dapat tercapai secara efektif. Pada saat pembelajaran materi geografi fisik pada kompetensi dasar menganalisis atmosfer dan dampaknya terhadap kehidupan di muka bumi, dengan menggunakan model pembelajaran inkuiri terbimbing, tingkat keaktifan peserta didik sangat berperan, seperti keterbukaan,

Berbagai kendala muncul pada saat penerapan model pembelajaran inkuiri terbimbing, seperti belum terbiasanya peserta didik dalam kegiatan belajar yang menggunakan model tersebut dan kurangnya waktu untuk kegiatan pembelajaran dengan menggunakan model pembelajaran inkuiri terbimbing.

Penggunaan model pembelajaran inkuiri terbimbing diharapkan dapat dijadikan alternatif pemilihan model pembelajaran yang dapat meningkatkan kemampuan aspek kognitif peserta didik khususnya pada mata pelajaran Geografi. 


\section{b. Saran}

Berdasarkan kesimpulan di atas, diajukan beberapa saran sebagai berikut:

1. Model pembelajaran inkuiri terbimbing dan model pembelajaran inkuiri bebas dapat dijadikan alternatif model pembelajaran bagi guru Sekolah Menengah Atas khusunya pada mata pelajaran Geografi.

2. Hasil penelitian menunjukkan bahwa model pembelajaran inkuiri terbimbing dapat memberikan pengaruh terhadap aspek kognitif peserta didik. Sedangkan model pembelajaran inkuiri bebas walaupun secara rata-rata nilai post tes lebih tinggi tetapi berdasarkan pengujian statistik pengaruhnya tidak signifikan terhadap aspek kognitif peserta didik. Hal ini harus diteliti lagi lebih lanjut dan lebih dalam lagi agar model pembelajaran inkuiri dapat lebih efektif untuk digunakan dalam pembelajaran terutama pembelajaran geografi.

3. Bagi peserta didik, diharapkan dengan model pembelajaran inkuiri terbimbing dapat berpengaruh terhadap peningkatan kemampuan aspek kognitif dengan berperan lebih aktif, karena dengan peranan yang baik dari peserta didik dapat menentukan keberhasilan proses kegiatan belajar mengajar.

4. Bagi guru, untuk menggunakan dan menerapkan model pembelajaran inkuiri harus menyesuaikan dengan materi pokok pembelajaran dan tujuan pembelajaran sehingga hasilnya akan lebih efektif.

5. Bagi sekolah, model pembelajaran inkuiri terbimbing dapat memberikan manfaat dan masukan untuk peningkatan hasil belajar peserta didik yang lebih baik, sehingga diharapkan sekolah dapat memberikan motivasi dan fasilitas penunjang untuk pengembangan model pembelajaran inkuiri terbimbing dalam pembelajaran Geografi.

6. Bagi kepala sekolah, untuk dapat memberikan kesempatan kepada para guru untuk menerapkan dan mengembangkan model-model pembelajaran yang lebih efektif, khusunya model pembelajaran inkuiri terbimbing. Sehingga tujuan pembelajaran dapat tercapai dengan baik.

7. Bagi penentu kebijakan, khususnya pada bidang studi Geografi di Sekolah Menengah Atas, model inkuiri terbimbing dapat dijadikan rujukan sebagai alternatif model pembelajaran dalam proses pembelajaran Geografi terutama pada pokok bahasan yang berkaitan dengan geografi fisik.

8. Dengan melihat hasil penelitian, maka diharapkan model pembelajaran inkuiri terbimbing dapat diterapkan pada pokok bahasan yang berkaitan dengan geografi fisik. 
9. Penelitian ini hanya mengukur kamampuan aspek kognitif peserta didik pada materi geografi fisik, maka bagi peneliti lainnya penulis memberikan saran agar dilakukan penelitian lanjutan yang berkaitan dengan model pembelajaran inkuiri terbimbing untuk melihat pengaruh tingkat kreatifitas dan berpikir kritis peserta didik. 